\title{
APPLICATION OF FUZZY MULTIPLE CRITERIA DECISION MAKING (MCDM) IN SELECTION OF PROSPECTIVE EMPLOYEES
}

\author{
Sutrisno, Sutikno Wahyu Hidayat, Avando Bastari,Okol S Suharyo \\ ${ }^{1}$ Indonesian Naval Technology College, \\ STTAL-Bumimoro-Morokrembangan, Surabaya 60187, Indonesia
}

\begin{abstract}
The recruitment process is the initial process that determines the sustainability and success of a company. In the process, effective and efficient selection tests are the key. The level of professionalism and academic ability of prospective employees are two things that are very much needed as a reference and criteria that are used as selection factors in the recruitment process. This study uses the Fuzzy Multiple Criteria Decision Making (MCDM) method by solving problems using the Simple Addictive Weighting Method (SAW). The use of this method is expected to produce an electronic selection test application that can help the recruitment team in carrying out the selection process at PT. X. The results of the research are in the form of prospective employee selection test applications to simplify the process of selecting prospective employees according to their needs.
\end{abstract}

Keywords: Selection Test, Application, FMCDM, SAW.

\section{INTRODUCTION.}

In this writing, the author takes data from PT. $X$ which is in a city of B. PT. $X$ is a company that continues to expand and always innovates by planning to open new branches in a period. Human resources are needed to carry out operational activities in it, either in the form of adding new employees or replacing employees who leave (resign), so that there is a need for the role of a recruitment team to carry out a good and appropriate selection process.

The process of receiving new employees at PT. $X$ is done routinely. This is done in order to get prospective employees who meet human resource standards of quality and integrity. The use of question sheets and answer sheets is still used when the selection test takes place because of the determination of prospective employees at PT. X still uses the selection system manually. The process of calculating the final score (scoring) also still uses the answer sheet that is matched with the test results of the selected participants. And determining the final value also still uses a very simple calculation system and there is no difference in weighting for each type of question. Therefore, a prospective employee selection test method was designed using the Fuzzy Multi Criteria Decision Making (MCDM) model with the Simple Additive Weighting (SAW) calculation method.

This method can be used to determine a decision that is multicriteria. This application is webbased with the help of an intranet (LAN) network. With the application, the test participants work on the problem of using a computer where the final value calculation process also uses a computer. This application is expected to facilitate the selection process and get qualified prospective employees according to the needs of each company.

Fuzzy MCDM is one of the methods developed and can be used to help decision makers in making decisions on several alternative decisions that must be taken by considering several criteria that will be taken into consideration to get accurate and optimal decisions that are expected to help and 
simplify the decision. Based on the description, the research was conducted with the Application of the Fuzzy Multi Criteria Decision Making (MCDM) method with the Simple Additive Weighting (SAW) calculation method in Selection of New Employee Candidates at PT. X.

The objectives to be achieved in this study are the Application of the Fuzzy Multi Criteria Decision Making (MCDM) method with Simple Additive Weighting (SAW) calculation method in the Selection of Prospective new employees at PT. X.

\section{MATERIAL/METHODOLOGY.}

\subsection{Application.}

The definition of the application according to experts is as follows:

a. According to (Anisyah, 2000), the application is the application, use or addition.

b. According to (Buyens, 2001), an application is a unit of software created to serve the needs of several activities.

c. According to (Dhanta, 2009), application (application) is software created by a computer company to do certain tasks, such as Microsoft Word and Microsoft Excel.

From some of the meanings above, it can be concluded that the application is software that functions to perform various forms of work and certain tasks such as the use, addition, and application of data.

\subsection{Selection Test.}

The test is a term derived from Old French, namely "testum" which means a plate to set aside precious metals. In Indonesian, the test is translated as a test or trial. The understanding of the test according to several experts is as follows:

a. According to (Sudijono, 2008), a test is a task or series of tasks given to individuals or groups of individuals, with the intention to compare their skills, one with another. b. According to (Arikunto, 2010), a test is a tool or procedure used to know or measure something in an atmosphere, by means and rules that have been determined.

From this understanding, it can be concluded that a test is a tool or procedure used to evaluate individuals and groups that have objective standards to observe one or more characteristics of a person whose results can be used as a basis for decision making. While the selection is the first attempt that must be made by the company to obtain competent and qualified employees who will serve and do all the work of the company.

According to experts the following are some definitions of selection:

a. According to (Yoder, 1981), the selection is a process of division into two prospective employees, namely prospective employees who will be accepted and who will be rejected.

b. According to (Rivai, 2008), the selection is an activity in HR management that is carried out after the selection recruitment process is carried out. This means that there have been a number of applicants who have met the requirements for which they can be chosen as employees in a company.

From several opinions, it can be concluded that the selection for the recruitment of new employees must be done carefully, honestly and objectively so that qualified employees and their proper placement can be obtained so that coaching, developing, controlling and regulating employees is relatively easy to achieve the desired goals. 


\subsection{Employee.}

According to the 1969 Law on Basic Provisions concerning Manpower in article 1, it is said that employees are workers who carry out work and provide their work to employers who work where the results of their work are in accordance with the profession or occupation on the basis of expertise as their livelihood. Some employee understanding according to experts:

a. According to (Hasibuan, 2002), employees are residents in working age (aged 15-64 years) or the total population in a country that produces goods and services if there is a demand for their labor and if they want to participate in the activity.

b. According to (Hasibuan, 2002), employees are people who sell services (mind or energy) and get compensation whose amount has been determined in advance.

Employees are people who have diverse human nature, feelings and needs. These needs are both physical and nonphysical, which must be met in order to live properly and humanely. This led to an approach based on employee welfare in personnel management.

\subsection{Multiple Criteria Decision Making (MCDM).}

MCDM is one of the most used methods in the retrieval area decision. The purpose of MCDM is to choose the best alternative from several exclusive alternatives that are mutually beneficial on the basis of general performance in various criteria (or attributes) determined by decision makers (kahraman, 2008). There are 2 basic approaches to the MCDM problem, namely Multiple Attribute Decision Making (MADM) and Multiple Objective Decision Making (MODM).
MADM makes decisions by paying attention to several attributes that are sometimes conflicting, whereas in MODM the number of alternatives is unlimited and reciprocal between criteria is described using continuous functions (Chou SY., 2008).

The use of the Fuzzy Multi Attribute Decision-Making (FMADM) approach, namely Fuzzy Simple Additive Weighting System (FSAWS) to solve the problem of selecting prospective employees by using objective / subjective attributes for decision-making groups. The proposed system integrates Fuzzy Set Theory (FST), Factor Rating System (FRS) and Simple Additive Weighting (SAW) to evaluate the alternative location of facilities. FSAWS is used for qualitative and quantitative dimensions. The FSAWS process considers the interests of each decision maker, and the total score for alternative locations is obtained from a homogeneous/heterogeneous decision-maker group.

In this study, a valuation model is used that uses a more intuitive Fuzzy MCDM technique in its application (Mazlum, 2015). So that it is expected that decision making with this model is useful as a positive input for the recruitment team in the process of selecting prospective employees who are at .

\subsection{Simple Additive Weighting (SAW).}

Simple additive weighting (SAW) is often also known as the weighted addition method. The basic concept of the SAW method is to find weighted sums of performance ratings on each alternative on all attributes (Fishburn, 1967) and (MacCrimmon, 1968). The SAW method requires the process of normalizing the decision matrix $(X)$ to a 
scale that can be compared with all available alternative ratings (Kusumadewi, 2006).

\subsection{Research Methodology.}

To solve problems in the observed research, steps are needed and determined to describe the approach and model of the problem. The steps taken are:



Fig. 1 Research Methodology Flowchart.

\section{RESULT AND DISCUSSION.}

\subsection{Testing Scenarios}

In this study the application of the FMCDM model with the SAW method was carried out with the following steps:

a. Determine the criteria that will be used as a reference in taking decisions, namely $\mathrm{Ci}$.

b. Determine the suitability rating of each alternative on each criterion.

c. Make a decision matrix based on criteria (Ci), then normalize the matrix based on the equation that is adjusted to the type of attribute (attribute gain or cost attribute) so that the normalized $\mathrm{R}$.

d. The final results were obtained from the ranking process, namely the sum of the multiplications of normalized matrices $R$ with the weight vector so that the largest value was chosen as the best alternative $(\mathrm{Ai})$ as a solution (Kusumadewi, 2006).

For each type of question criteria, criteria and importance rating criteria (preference weight) each criterion used in this application is tailored to the interests of PT. X Branch $A$. The following are the criteria and conditions used to determine the passing of the test participants, among others, Problem A (C1), Problem B (C2), Problem C (C3), Problem D (C4), Problem E (C5).

From these criteria, a level of importance of criteria is made based on weighted values that have been determined in fuzzy numbers. The suitability rating of each alternative (assessor) on each criterion is as follows, Low Once $(R S)=0$, Low $(R)=0.25$, Enough $(C)=0.5$, Good $(B)=0.75$, Very Good $(B S)=1$ (Dubois \& Prade, 1979)

Based on the criteria and rating of the suitability of each alternative on each predetermined criterion, then the description of the weight of each criterion that has been converted to fuzzy numbers. The criteria used in the test provisions for each question are the same as follows.

Table 1. Interest Rating Table

\begin{tabular}{|l|l|l|l|}
\hline No. & Linguistic Value & Range & Value \\
\hline 1. & Very Low & $0-24$ & 0 \\
\hline 2. & Low & $25-49$ & 0,25 \\
\hline 3. & Enough & $50-74$ & 0.5 \\
\hline 4. & Good & $75-89$ & 0,75 \\
\hline 5. & Very Good & $90-100$ & 1 \\
\hline
\end{tabular}


In this application, for each value given by each alternative, each criterion is a matching value (the largest value is best), then all the criteria given are assumed to be the profit criteria. So the equation is used (Equation (1), namely:

$$
r_{i j}=\left\{\frac{X_{i j}}{\max _{i} X_{i j}}\right.
$$

Where rij is a normalized performance rating of alternative $\mathrm{A} 1$ in the $\mathrm{C} j$ attribute; $\mathrm{i}=$ $1,2, \ldots, m$ and $j=1,2, \ldots, n$. The preference value for each alternative (Vi) is given (Equation (2) as:

$$
V_{i}=\sum_{j=1}^{n} w_{j} r_{i j}
$$

A larger $\mathrm{Vi}$ value indicates that alternative $\mathrm{Ai}$ is more chosen. The following is an example of problem solving using FMCDM using the SAW method based on the data above. From several test results, three sample test results were taken with the following values:

Table 2. Test Value Tables

\begin{tabular}{|c|c|c|c|c|c|}
\hline \multirow{2}{*}{ Name } & \multicolumn{5}{|c|}{ Test Value } \\
\cline { 2 - 6 } & A & B & C & D & E \\
\hline Yunita & 44 & 30 & 20 & 52 & 48 \\
\hline Robert & 82 & 95 & 80 & 72 & 60 \\
\hline Fardan & 62 & 55 & 30 & 64 & 48 \\
\hline
\end{tabular}

Based on table 3.2 above, a compatibility rating is based on the graduation criteria table in the previous data using fuzzy values.

Table 3. Fuzzy Value Tables

\begin{tabular}{|l|c|c|c|c|c|}
\hline \multirow{2}{*}{ Name } & \multicolumn{5}{|c|}{ Fuzzy Value } \\
\cline { 2 - 6 } & A & B & C & D & E \\
\hline Yunita & 0,25 & 0,25 & 0 & 0,5 & 0,25 \\
\hline Robert & 0,75 & 1 & 0,75 & 0,5 & 0,5 \\
\hline Fardan & 0,5 & 0,5 & 0,25 & 0,5 & 0,25 \\
\hline
\end{tabular}

Steps to Settle:

a. The first step, the matrix formed from the table match as follows:

$$
X=\left\{\begin{array}{lllll}
0,25 & 0,25 & 0,00 & 0,50 & 0,25 \\
0,75 & 1,00 & 0,75 & 0,50 & 0,50 \\
0,50 & 0,50 & 0,25 & 0,50 & 0,25
\end{array}\right\}
$$

b. The second step, normalize the $\mathrm{X}$ matrix based on equation (1) as follows:

1) Yunita

$$
\begin{aligned}
& \mathrm{r}_{11}=\frac{0,25}{\max \{0.25: 0.75: 0.50\}}=\frac{0,25}{0,75}=0,33 \\
& \mathrm{r}_{12}=\frac{0,25}{\max \{0,25 ; 1,00 ; 0,50\}}=\frac{0,25}{1,00}=0,25 \\
& \mathrm{r}_{13}=\frac{0,00}{\max \{0,00 ; 0,75 ; 0,25\}}=\frac{0,00}{0,75}=0,00 \\
& \mathrm{r}_{14}=\frac{0,50}{\max \{0,5 ; 0,500 ; 0,50\}}=\frac{0,50}{0,50}=1,00 \\
& \mathrm{r}_{15}=\frac{0,25}{\max \{0,25 ; 0,50 ; 0,25\}}=\frac{0,25}{0,50}=0,50
\end{aligned}
$$

2) Robert

$$
\begin{aligned}
& \mathrm{r}_{21}=\frac{0,75}{\max \{0,25 ; 0,75 ; 0,50\}}=\frac{0,75}{0,75}=1,00 \\
& \mathrm{r}_{22}=\frac{1,00}{\max \{0,25 ; 1,00 ; 0,50\}}=\frac{1,00}{1,00}=1,00 \\
& \mathrm{r}_{23}=\frac{0,75}{\operatorname{mid}\{0,00 ; 0,75 ; 0,25]}=\frac{0,75}{0,75}=1,00 \\
& \mathrm{r}_{24}=\frac{0,50}{\max \{0,50 ; 0,50 ; 0,50\}}=\frac{0,50}{0,50}=1,00 \\
& \mathrm{r}_{25}=\frac{0,50}{\max \{0,25 ; 0,50 ; 0,25\}}=\frac{0,50}{0,50}=1,00
\end{aligned}
$$

3) Fardan

$$
\begin{aligned}
& \mathrm{r}_{31}=\frac{0,50}{\max \{0,25 ; 0,75 ; 0,50]}=\frac{0,50}{0,75}=0,67 \\
& \mathrm{r}_{32}=\frac{0,50}{\max \{0,25 ; 1,00 ; 0,50]}=\frac{0,50}{1,00}=0,50 \\
& \mathrm{r}_{33}=\frac{0,25}{\max \{0,00 ; 0,75 ; 0,25]}=\frac{0,25}{0,75}=0,33 \\
& \mathrm{r}_{34}=\frac{0,50}{\max \{0,5 ; 0,50 ; 0,50]}=\frac{0,50}{0,50}=1,00 \\
& \mathrm{r}_{35}=\frac{0,25}{\max \{0,25 ; 0,5 ; 0,25]}=\frac{0,25}{0,50}=0,50
\end{aligned}
$$

Based on the results of the $X$ matrix normalization, the $\mathrm{R}$ matrix is formed as follows:

$$
R=\left\{\begin{array}{lllll}
0,33 & 0,25 & 0,00 & 1,00 & 0,50 \\
1,00 & 1,00 & 1,00 & 1,00 & 1,00 \\
0,67 & 0,50 & 0,33 & 1,00 & 0,50
\end{array}\right\}
$$


Where the maximum value for each type of question is as follows:

$$
W=\left(\begin{array}{lllll}
0,75 & 1,00 & 0,75 & 0,50 & 0,50
\end{array}\right)
$$

Then the multiplication matrix $\mathrm{W} \times \mathrm{R}$ is made and the sum of the multiplication results to obtain the best alternative by ranking the largest value using equation 2 shows the following results:

$$
\begin{aligned}
& \text { V1 } \\
& \{(0,75)(0,33)+(1,00)(0,25)+ \\
& (0,75)(0,00)+(0,50)(1,00)+ \\
& (0,50)(0,50)\} \\
& =1,25 \\
& V 2= \\
& \{(0,75)(1,00)+(1,00)(1,00)+ \\
& (0,75)(1,00)+(0,50)(1,00)+ \\
& (0,50)(1,00)\} \\
& =3,50 \\
& V 3= \\
& \{(0,75)(0,75)+(1,00)(0,60)+ \\
& (0,75)(0,50) \mid(0,50)(1,00) \\
& (0,50)(1,00)\} \\
& =2,00
\end{aligned}
$$

\section{CONCLUSION.}

The main result of this system is to determine the ranking sequence of the new prospective employee selection participants according to the criteria and needs of each part of the PT. X.

The results of the system test will determine the prospective employee who has the highest score based on the specified criteria that will be selected as an employee in a certain part. Based on the results of the system testing on the Prospective Employee Selection Test Application using the Multiple Fuzzy Method at PT. X obtained by the average value of the results of the system trial is 3.7 (scale 4). this means the system validation is functioning properly.

a. With this electronic selection test system, the selection test process can run more easily and the final value calculation process using Fuzzy Multiple Criteria Decision Making (MCDM) with problem solving using the Simple Addictive Weighting Method (SAW) is faster and more accurate.

b. The results of the system test on the Prospective Employee Selection Test Application Using Fuzzy Multiple Criteria Decision Making (MCDM) with problem solving using the Simple Addictive Weighting Method (SAW) at PT. X obtained by the average value of the results of the system trial is 3.7 (scale 4) means it has been functioning properly.

\section{BIBLIOGRAPHY.}

Anisyah, S.N.R.S. (2000) Kamus Lengkap Bahasa Indonesia, Surabaya: Sinar Terang.

Arikunto, S. (2010) Prosedur Penelitian Suatu pendekatan Praktik, Jakarta: PT. Rineka Cipta.

Buyens, J. (2001) Web Database Development, Jakarta: Elex Media Komputindo.

Chou SY., C.Y..S.C. (2008) 'A fuzzy Simple additive weighting system under group decision making for facility location selesction with objective/subjective attributes', european journal of operational research 189 (1), pp. 132-145.

Dhanta, R. (2009) Kamus Istilah Komputer, Grafis dan Internet, Surabaya: Indah.

Fishburn, P.C. (1967) 'Additive Utilities wih Incomplete product Set : Application to Priorities and Assignments'.

Hasibuan, M.S.P. (2002) Manajemen Sumber Daya Manusia, Edisi Revisi, Jakarta: PT. Bumi Aksara. 
kahraman, c. (2008) Fuzzy Multicriteria Decision Making: Theory and Applications with Recent Development, Turkey: Springer.

Kusumadewi, S.h.S..H.A..W.R. (2006) Fuzzy MultiAtribut Decision Making (Fuzzy MADM), Yogyakarta: Graha IImu.

MacCrimmon, K.R. (1968) Decision making among Multiple Attribute Alternatives. A Survey and Consolidated Approach, Santa Monica: CAL.

Mazlum, M. (2015) 'CPM, PERT and Project Management With Fuzzy Logic Technique and Implementation On A Business', 4th International Conference on Leadership, Technology, Innovation and Business Management, Istanbul, 348-357.

Rivai, V. (2008) Manajemen Sumber Daya Manusia untuk Perusahaan, Bandung: PT.Remaja Rosda Karya.

Sudijono, A. (2008) Pengantar Evaluasi Pendidikan, Jakarta: PT.Rajagrafindo Persada.

Yoder, D. (1981) Personnel Management and Industrial Relations, New Delhi: Prentice Hall of India. 